\title{
Breaking the age barrier
}

\section{Many scientists continue to run productive and innovative research programmes well beyond typical retirement age. But in many countries, tough retirement laws make staying in the lab a challenge. Laura Bonetta reports.}

$\mathbf{W}$ hen Jack Strominger and his wife moved to an apartment just a 15-minute walk from the lab, Strominger thought he would be able to do his reading and writing from home. Yet he rarely makes it out of the office before six in the evening. The head of a 14-member group at Harvard University, Strominger has an ambitious research agenda by any standards, but even more so because he turned 80 this month.

The immunologist is best known for his work with Don Wiley on the proteins that the body uses to distinguish its own cells from foreign ones. But these days, he enjoys applying his years of experience to new problems, such as autoimmune diseases. "My goal has always been to stay original," he says. "When I can't do that any more, maybe I will spend more time riding horses at our farm."

Eighty-year-old Janet Rowley, a cancer geneticist at the University of Chicago, has also toyed with the idea of slowing down. "I was thinking of going part-time but wanted to see what would happen to my latest grant," she says. "We got funding for another three years, so now I can postpone that decision." Rowley made her mark by discovering that pieces of chromosomes in cancer patients can break off and join on to other chromosomes. She had something of a late start in research, having worked as a dinician for several years and then as a part-time researcher while raising four sons. But she has more than made up for lost time. "I have had a front-row seat in a neverending suspense story," she says.

Such tales are not unique. Many researchers continue to lead active and innovative research programmes in their 70 s and 80 s, quashing the notion that science is a young person's game. "Age matters, but not that much. And it matters less in the life sciences than in physics," says Paula Stephan. An economist at Georgia State University, Atlanta, Stephan co-wrote a book in 1992 called Striking the Mother Lode in Science: The Importance of Age, Place and
Time, in which she examined the relationship between age and productivity based on publication record.

There may even be some advantage to age. "It can maybe help you focus on larger problems," says Joseph Gall of the Carnegie Institution in Baltimore, Maryland, who at 77 still works at the bench all day. "If you feel you have made your mark, you can sit back and look at the bigger picture. In a way that is what happened with our work on the Cajal body." First described more than 100 years ago, this cell structure was brought out of obscurity in the past decade by Gall's work showing that it is the assembly site in cells for key proteins that modify RNA molecules to make them function.

\section{Generation gap}

But there are drawbacks too. "It is definitely harder to recruit students and postdocs," says Strominger. "But it is understandable. My grandchildren are almost the age of my students. It is harder to relate to your grandfather."

Writing grants can also begin to get tedious after so many years. At 86, Herman Eisen, an immunologist at the Massachusetts Institute of Technology (MIT) in Cambridge, decided to let his last federal grant run out. "It was unrealistic to keep writing grants," he says. ${ }^{\alpha}$ For one thing, I had stopped taking postdocs because I could not commit to them for several years. And also on some level it felt embarrassing; I would be competing with former postdocs and students."

But Eisen is not out of work. MIT let him keep his lab space, where he continues to plug away at the bench aided by a part-time assistant and a succession of undergraduate students. "It is still very fascinating. The problems I choose today are precisely those that appeal to me a lot," Eisen says.

The lure of finding one more piece of the puzzle is what keeps thoughts of leaving research at bay for many ageing scientists. ${ }^{\circ} \mathrm{I}$ can't think of a day that I did not want to come to the lab. Maybe when my papers start getting
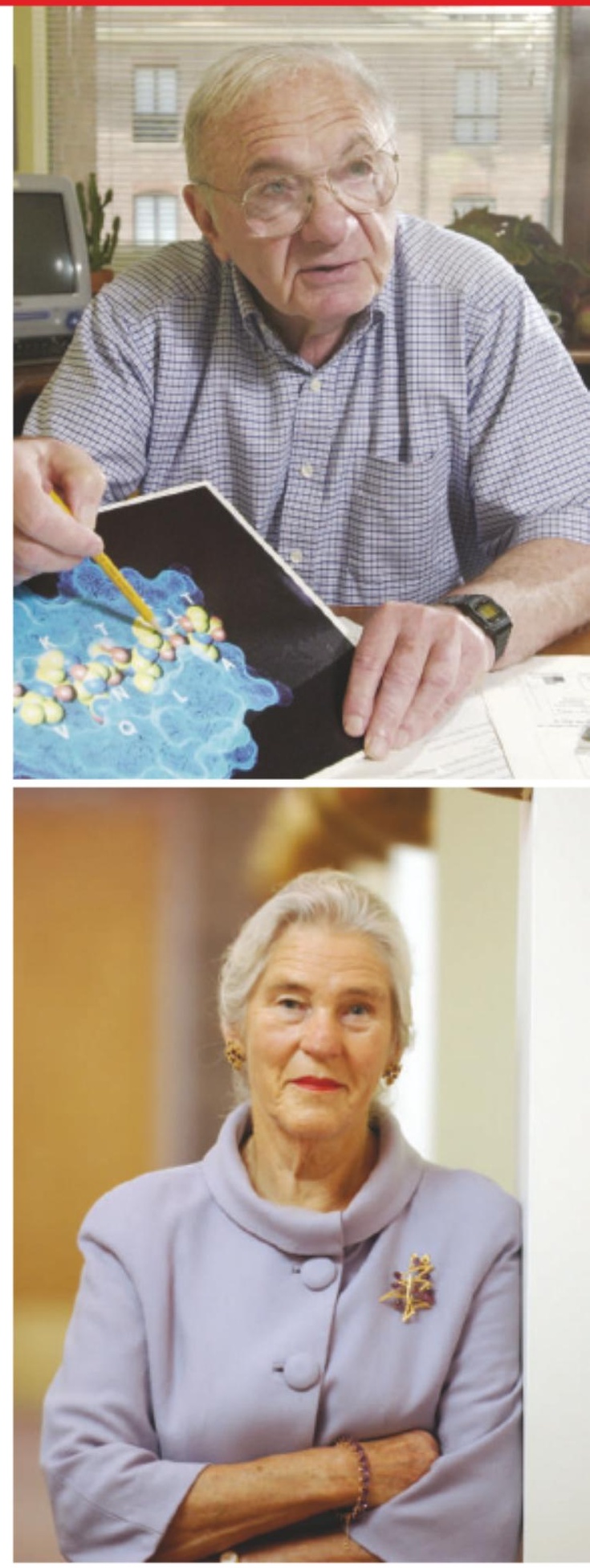

rejected, I will start thinking about doing something else," says Gall.

Scientists in the United States can continue working as long as they can get grants because the country did away with mandatory retirement in 1994. Australia, New Zealand and some provinces of Canada have followed suit. But in many European countries and in Japan, scientists working at government-funded universities have little choice but to retire sometime between the ages of 60 and 70 , regardless of their level of productivity. As a result, the United States has benefited from the influx of several superstar foreign scientists trying to escape this fate. 
